\title{
US court case to define EST patentability
}

On May 3, the first case appealed to the US Court of Appeals for the Federal Circuit concerning the patentability of expressed sequence tags (ESTs) is due to start, following a dispute between St. Louis, Missouri-based Monsanto and the US Patent and Trademark Office (USPTO). The case is likely to clearly define how much knowledge a patentee needs to have of how newly discovered ESTs work and whether the defined use meets the USPTO requirement of specific and substantial utility. If favorable to Monsanto, the judgment could annihilate or support longstanding efforts by the biotech research community to work with a stricter definition of 'utility' in patenting.

The issues related to DNA patenting have been debated for more than a decade. The May court case, In re Fisher, is the latest development in a long series of discussions since the early nineties between the USPTO, the National Institutes of Health, the National Academy of Sciences, and other government agencies and academic institutions, and the biotechnology and pharmaceutical industry attempting to define the appropriate scope of DNA-related patent claims and the invention's utility.

In Fisher, the specific question is 'how much does a patentee have to know about the function and role of ESTs to actually patent them'? The patent application under scrutiny was initially submitted by Monsanto and then rejected by the USPTO on the grounds that its claims in the written description of the invention were too broad and that it didn't sufficiently demonstrate "specific and substantial" use of the invention.

This decision was appealed by Monsanto within the USPTO and the rejection upheld, although the issue of overly broad claims was dismissed whereas the lack of utility was affirmed by the USPTO's appeals board. The federal circuit court is expected to rule on the matter sometime this summer; then if either party appeals the decision, the case could make its way to the US Supreme Court.

ESTs are a sequence or fragment of DNA, which may or may not code for a particular protein. These proteins can enable a researcher to trace back and determine both the proteins' RNA and DNA, thereby potentially linking a disease or biological process to the DNA associated with it. This 'linking' would qualify as "specific and substantial utility," if disclosed. The vexing intellectual property issue in Fisher is to determine when researchers have enough knowledge of this process to lay claim to particular ESTs. In this court case, a general, nonspecific utility is defined in the patent. Monsanto's plant ESTs described in the patent application aren't linked to any particular biological or disease process.

This can be a problem, notes the Washington, DC-based Biotechnology Industry Organization's director of intellectual property Lila Feisee. "It's not very complicated to find ESTs. It's not like you've done invention of any sort, basically anyone can do it." BIO does not have an official position on EST patents.

Monsanto, even though it is a voracious patent acquirer, may not be clinging fiercely to this patent case out of the desire to further expand its patent portfolio. Some industry observers have speculated that Monsanto floated this as a test case. "It's a very important test," noted the senior vice president of the division of biomedical and health sciences research of the Washington, DC-based Association of American Medical Colleges (AAMC) David Korn. “I wouldn't be amazed if somebody from Monsanto said they were doing this deliberately to test the guidelines."
Although, Monsanto could not comment due to the pending litigation, the court case could indeed serve to codify the most recent guidelines issued by the USPTO in 2001 the utility of an invention intended to address patenting of genetic and related information.

Along with several other parties including Eli Lilly and Dow AgroSciences, both of Indianapolis, Indiana, the National Academy of Sciences and the AAMC are part of an amicus brief in support of the USPTO filed against Monsanto in the federal case. The basis of their opposition is straightforward: by many in the research community, ESTs are seen as research tools that should be part of the public domain unless they are clearly defined in relation to specific biological processes.

Some are concerned that if EST patent applications with overly broad claims-many are worded so as to potentially annex any adjacent nucleic acids which could theoretically expand it out to the entire chromosome-or nonspecific utility are approved, it could have implications for other homologous, genetic processes. Although ESTs have largely faded from the current forefront of research, this would affect areas of biotech research still in vogue such as kinases, which are also based on homologous processes.

If the court favored Monsanto, it would be going against the utility requirements of the USPTO. Such a scenario would potentially open the door for increasingly less specific patents thus threatening a decade of work by the USPTO and the biotechnology research community to define utility strictly.

"It's akin to the old Spanish, English and Portuguese explorers," concludes Korn. “They would take their boats until they found some edge of land, then they would go up and plant the flag of their king or queen. They didn't know what they'd discovered; how big it is, where it goes to-but they would claim it anyway."

Stacy Lawrence, San Francisco

For more news and analysis go to news@nature.com www.nature.com/news 